\title{
NEW PUBLIC MANAGEMENT: US EXPERIENCE FOR UKRAINE
}

Vitalii Khomytskyi, Student, Master of Public Administration, Taras Shevchenko National University of Kyiv (Ukraine),

ORCID: https://orcid.org/0000-0001-7909-7666,

Email:vitalii.khomytskyi@gmail.com

\begin{abstract}
Purpose. The purpose of the article is to analyse the effectiveness of reforms based on new public management concept in the United States and identify key elements for implementation in Ukraine.

Methodology. The results of the study were obtained by the following methods: systematic and comparative methods - to determine the nature and features of the historical formation of new public management reforms in the United States, based on understanding administrative activities through the prism of private economy, public service orientation on efficiency and effectiveness; methods of analysis and synthesis - to identify complex historical factors and interests that led to the formation and functioning of the new public management system.

Findings. In accordance with the study objectives, the author:

1) established and analysed the theoretical sources and methodological principles of the study of the concept of new public administration by T. Goebler and D. Osborne;

2) clarified the significance of the concept of the new public administration of T. Goebler and D. Osborne for the system of modern scientific research of the public sector;

3) revealed the meaning of the concept of new public administration as an administrative process;

4) analysed the problems of public administration efficiency in the context of the concept of new public management during the reforms in the United States;

5) identified the possibilities of applying the concept of new public management in carrying out reforms of modern administration processes in Ukraine.

Originality. Author has proposed vision and interpretation of historical factors that led to the formation of a new public management. The article contains an analysis of the historical events and the practical consequences of the reforms in the United States.

Practical value. Regarding the government change in Ukraine and the volatile economic situation due to the coronavirus pandemic, the implementation of elements of new public management concept might help increase the effectiveness of civil service reform in Ukraine. The materials of the article can be used in the practice of public administration; in the development of courses in public administration; to improve training programs and plans for government officials; in preparation of textbooks, educational and methodical manuals.
\end{abstract}

Keywords: state management, new public management, new managerialism, reform.

Received: 29.03.2019

Accepted for publication: 13.05 .2019

Published: 18.06.2019

Khomytskyi, V. (2020). New Public Management: US Experience for Ukraine. Bulletin of Taras Shevchenko National University of Kyiv. Public Administration, (11), 46-52. https://doi.org/10.17721/2616-9193.2019/11-5/7

Introduction. The article is devoted to the analysis of reforms in the context of the New Public Management, which is based on the understanding of administrative activity through the prism of the private economy, the orientation of the civil service on the efficiency and effectiveness of the management process. 
Examining the experience of reforms in the United States, the author justifies the need to apply elements of the concept of new public management in Ukraine.

In order to determine whether this compromise has happened, the objective of the article is as follows:

Objective 1: The article will review theoretical sources and methodological principles of the study of the concept of new public administration by T. Goebler and D. Osborne.

Objective 2: The article will clarify the significance of the concept of the new public administration of

T. Goebler and D. Osborne for the system of modern scientific research of the public sector.

Objective 3: The article will reveal the meaning of the concept of new public administration as an administrative process.

Objective 4: The article will analyse the problems of public administration efficiency in the context of the concept of new public management during the reforms in the United States.

Objective 5: The article will identifie the possibilities of applying the concept of new public management in carrying out reforms of modern administration processes in Ukraine.

\section{Analysis of the recent achievements}

Solving the key tasks facing Ukraine, in particular the growth of economic dynamics, increasing and maintaining growth rates, achieving social harmony, requires a comprehensive overhaul of the governance system in Ukraine. Such a system is the New Public Management (hereinafter - NPM). During the reforms in many developed countries, such as the United States, Great Britain, Sweden, Germany, France, and New Zealand, the principles and mechanisms of the New Public Management were used.

An important problem that needs further research is the renewal of the integrated system of governance in Ukraine, which should become a real precondition for solving the basic tasks of our country in the context of European and Euro-Atlantic integration and globalization of the modern world. A new system of governance, based on modern world trends and the experience of countries with developed economies, would allow to realize the potential of Ukraine and contribute to the achievement of national interests.

The aim of the work is to analyse the mechanisms of implementation of new public management in the United States of America and provide recommendations for the application of elements of the concept of New Public Management in Ukraine.

\section{Presentation of the main research}

The new public management has played an important role in the formation of public administration due to the focus of this model on the effectiveness and efficiency of the management process, which distinguishes it from other approaches. The new model of public administration is the result of a long process of formation and creation. When developed countries faced the problem of lack of resources, including lack of funding, but had to solve global problems. The main principles and features of the new model of public administration were borrowed from the market economy sector. Their transposition into the organizational model and practices of state structures took place in the second half of the 1970s.

From now on, the NPM is the model of sovereign governance, based on the principle of corporate governance, as well as business and non-profit organizations. This new model of management is based on increased efficiency in the government, the reduction of hierarchy, delegation of importance, and the increase in power.

The most significant studies on New Public Management are highlighted in the works, first of all, of such well-known foreign researchers, as T. Piters, R. Waterman, D. Osborne, T. Gaebler, D. Ketl, O. Hughes, K. Hood, E. Schroter, L. Jones, F. Thompson, A. Gore, M. Thatcher, P. Plastrik, A. Link, D. Evalt, R. Stephenson and the others.

The impetus for the spread of the term "management", which entered the language of both businessmen and US civil servants, was the publication in 1982 of the book "In Search of Effective Governance", which became a kind of desktop book for public administrators. The book's authors, T. Peters and R. Waterman, studied the work of corporations such as Boeing, IBM, and McDonald's, which they described as "perfection itself." They found that these companies have a number of common characteristics that could be borrowed and used in government agencies, including: 
1. Tendency to action. An effective organization takes effect immediately, while government officials analyse, consult, but do not make decisions until instructed to do so. It is necessary to become more flexible, to move away from traditional patterns of formal response, from rigid fixed organizational structures that impair performance.

2. Be closer to the customer. An effective organization listens carefully to the client's requests and responds to his requirements. Otherwise, they go bankrupt. The main part of state organizations is not threatened and is not an influential factor. For example, local authorities have a monopoly on the provision of many services that are no longer provided by anyone. Public services are too often busy with themselves, not customers.

3. Independence and persistence. People should be encouraged to show responsibility and initiative, to give up routine and to obey instructions.

4. Efficiency through people. Every employee of the corporation is stimulated to offer innovation decisions and improve their work, which serves to improve the work of the corporation as a whole. The corporation has an atmosphere when employees make high demands on each other. In the public sector, the emphasis is on reducing costs, rather than improving the quality of services or the interest of employees, which often begins to affect the level of motivation of people.

5. Concentration at work. People who work in a corporation mostly share its overall value system and have as their motivation the goal of the corporation itself. It is well known that policy priorities change over time. If civil servants share the priorities of one party, are they able to work if another party comes to power? Obviously, it is possible to avoid such a situation if we take as a basis such priorities as professionalism, concentration on specific requirements of the client or local communities.

6. Choice of field of activity. The corporation must be able to find the type of activity for which it is most suitable. Public institutions, in turn, perform only those activities that are provided by law. A private corporation, unlike a government agency, can quickly cease to engage in one activity and move on to another, focusing on customer needs and status.

7. Simplicity and logic of structure. An effective organization has a simple structure with a small number of hierarchical levels. This approach contradicts the traditional bureaucratic structure with a large number of hierarchical levels and a direct vertical of power.

8. A combination of "hardness" and "softness". The implementation of the main goals and vectors of activity is controlled from above; at the same time, the lower hierarchical levels are independent in actions that contribute to the achievement of these goals.

The general principles of the organization of the model of new public administration had been formulated by well-known ideologues and practitioners of these reforms D. Osborne and T. Goebler. They have been named the principles of restoration of modern public administration systems, in particular:

1) coordinate management functions more than perform them;

2) provide consumers with more choices than serve them;

3) provide services on a competitive basis;

4) manage the setting of tasks rather than defining rules;

5) invest capital in results, not in intentions;

6) focus on the consumers;

7) encourage the entrepreneurial spirit of making money, not bureaucratic spending;

8) give preference to prevention over treatment;

9) carry out structural decentralization and establish cooperation between decentralized structures;

10) achieve change through market-oriented efforts.

In 1980-1990, the United States formulated proposals for restructuring the system of public administration on the model of market institutions. The path from theory to practice was paved by a commission of US Vice President Albert Gore, which stated that American state structures had become inefficient and closed to citizens monopolies and proposed a complete reform of public administration. As a result, the country has developed and implemented a model of "result-oriented" public sector, in which the result meant services to citizens and their organizations, the latter's satisfaction with the functioning of the public authority. 
In 1993, the US government embarked on a reform called "re-establishing governance." These reforms took place in an extremely politicized environment. On the one hand, US reforms included more governance components and were implemented in a shorter time than in other countries. On the other hand, because of the politicization of reforms, they focused on changing the behaviour of bureaucrats, rather than changing the structure and processes of governance. The reformers also sought to reduce the cost and efficiency of services provided to consumers by the federal government. To this end, the United States was decentralizing the bureaucracy, as well as delegating federal powers to lower levels of government. In the United States, the privatization of public functions was rather limited, and the emphasis was on the partnership between the state and private enterprises.

The main large-scale goal set by the government during the reforms was to redefine the nature of the state and the nature of its relations with citizens.

The above principles of restoration of public administration systems, defined by D. Osborne and $\mathrm{T}$. Goebler, allow us to conclude that the reforms of the new public management are dominated by two trends: economic - marketing and organizational - debureaucratization. Modern public administration institutions must be flexible to respond quickly to complex and rapidly changing conditions. The bureaucratic system is ineffective due to its own regulations.

The content of marketing is the introduction into the practice of the state apparatus of market mechanisms in the broadest sense. Marketing involves the separation of the structure of public administration from the functions of policy definition and regulation, supervision and production of services. A common tool in this part is to take out of the administrative hierarchy of state organizations directly engaged in the production and provision of services to the population.

Debureaucratisation is an organizational support for economic imperatives focused on the efficiency of the public sector as a whole. The main content of debureaucratisation includes the following elements:

- change of principles of formation of organizational structure of public administration (decentralisation and deconcentration instead of centralisation and concentration of domination of a functional structure contrary to branch, integration instead of specialisation and differentiation, etc.);

- change in the composition and content of public administration functions, their structure; emergence in addition to the traditional functions of forecasting, strategic analysis, evaluation and planning, marketing of resources, products, consumers, human resource management of institutions, financial management, etc; strengthening and organizational separation of analysis, evaluation and coordination functions and their concentration at higher levels of government;

- change the principles of staffing units (teams, committees and working groups) on the basis of meaningful qualification, instead of formal criteria;

- change the system of planning, reporting and control;

- change the system of work evaluation, stimulation and control of personnel;

- change the system of rewards, establishing their dependence on the result of work;

- increasing staff mobility;

- review and cancellation of work types and operations that are not focused on the end result;

- total focus on productivity and quality of works and services;

- reduction of the number of administrative staff.

The introduction of managerialism in the activities of state organizations includes the establishment of five types of individual accountability as a necessary minimum for a responsible official:

1) legal control (legislative regulation)

2) financial control (how public funds are spent);

3) the standpoint of policy implementation (achievement of the stated goals);

4) democratic control (communication with citizens);

5) ethical control (actions in accordance with ethical norms).

The concepts of D. Osborne and T. Goebler, T. Peters and R. Waterman were formulated in the spirit of the theory of "New Public Management" influential in modern (primarily Anglo-Saxon) administrative science. More often than others, one can hear the definition of "new managerialism", which means that management ideas, which have largely emerged in the private sector, have supplanted the concepts of traditional public administration. Such changes have been called the three "E" - economy, energy and efficiency - and 
have profoundly affected the understanding of both the role of government in determining public policy and the status of civil servants.

Traditional bureaucratic methods of public administration from the standpoint of the new public management have been criticized, and the market, or rather markets in various fields, had been seen as something opposite and positive.

The reforms focused on solving such important problems as political, administrative, and bringing the state closer to the citizens.

To a greater extent, a political problem focused on the question "what should the state do?" Can be solved only if it relies on the political system of the state. The administrative and efficiency issues, in turn, focus on "how can the state do better?" Addressing this issue requires strong political governance and support.

The reforms should have resulted in increased public confidence, as signs of declining confidence were evident, especially in the 1990s, when citizens remained supporters of pro-democracy as a form of political system but were dissatisfied with the way democracy functioned in the country. In many cases, such dissatisfaction serves as a powerful driver for administrative reform.

The problem of efficiency in all its forms - economic, social, organizational was placed at the centre of reform. By the mid-1990s, 39 states had reported measures to improve the quality of governance, thus revealing political will, which ultimately led to positive results. One of the main components of the reforms was to increase the importance and responsibility of the lower levels of government. In general, the service delivery process should have become more transparent to the public, and departmental barriers should not hinder this process.

New Public Management was perceived to become a solution of many problems that had traditionally beset public administration. Aside from other things, it escalated within the context of an ideological shift in the role of public service provision, the welfare state, employment, new technology and in the role of governments and markets in the management of services. In the early 2000s, the concept seemed to have been replaced by a reemphasis on new ways of stakeholder engagement in the governance process. Since the financial crisis of the late 2000s, many of the central themes of NPM have returned to the political agenda, though in a new form and reframed in terms of the inclusiveness and empowerment qualities of the public sector rather than the efficiency of the private sector.

\section{Summary, Final Conclusions and Comment}

Public administration reforms are not only government's matter, it requires broad participation of citizens, close cooperation between state and non-state institutions, especially in defining the goals and objectives of reforms. Efforts to reform public administration have to be in line with society's values and norms.

Through the practice of reforms has been shown the growing importance of different ways of providing services that differ from traditional ways of management. In the XXI century, public administration in the United States will increasingly rely on non-governmental institutions, and this requires the establishment of closer institutional interdependence of governmental and non-governmental organizations and institutions and their functional efficiency.

As a result of the reforms carried out in the spirit of the new public management, the level of importance and responsibility of the lower levels of government has increased. This process will continue to intensify, which will make us to pay more attention to the distribution of management roles.

Initial attention was paid to the coordination of mechanisms for providing services to the population within the framework of public administration - the process of providing services should become more accessible and transparent for citizens.

The reforms of the new public management are dominated by two tendencies: economic - marketing and organizational - debureaucratization. The content of marketing is the introduction into practice of the state apparatus of market mechanisms, debureaucratization - organizational support of economic imperatives focused on the efficiency of the public sector as a whole.

It is established that globalization has a direct impact on the process of public administration. The government must be prepared to make important decisions together with other national state and transnational corporations. 
Reforms in the United States have generally increased the productivity of the civil service, improved the quality of public services, and reduced their costs. As a result of the reforms, the civil service has become closer to its citizens. According to the author, Ukraine needs to introduce elements of the concept of a new public management, which will bring the civil service closer to citizens, improve the quality of services and, above all, identify what the population really needs. Today there are successful practices of implementation of NPM tools in cities and regions of Ukraine, in particular of implementation of pilot projects, marketing tools, single window, benchmarking practices.

Prospects for further research.

In the context of the study, in our opinion, it is advisable to create a scientific and practical basis for a gradual transition of public administration, which would correspond to the new management paradigm, which significantly reduces the resistance of the existing bureaucratic machine. It is based on recognition of priorities such as customer focus, consumer of management and civil services and bringing management closer to it. As well as increasing management flexibility, readiness for change, introduction of market methods, achievements and tools of management and marketing. Making entrepreneurial approaches improve the effectiveness and efficiency of management, implementation of a new organizational culture of public management, balance of political and administrative factors of management.

\title{
References
}

Andrews, R. NPM and Search for Efficiency [Text] // The Ashgate Research Companion to New Public Management. - Burlington: Ashgate Publishing Company, 2013. - PP. 281-294.

Donald, F. Kettl. The Global Public Management Revolution. A Report on the Transformation of Governance. - Washington: Brookings Institution Press, 2000. - VII.

Gore 'Creating a Government that Works Better and Costs Less: Report of the National Performance Review’ (1993). - PP. 1-6.

Jo Ann G. Ewalt. "Theories of Governance and New Public Management: Links to Understanding Welfare Policy Implementation". - Department of Government Eastern Kentucky University, American Society for Public Administration, Newark, NJ.

Jo Ann G. Ewalt. 'Theories of Governance and New Public Management: Links to Understanding Welfare Policy Implementation'. - Department of Government Eastern Kentucky University, American Society for Public Administration, Newark, NJ. - PP. 2-7.

Hughes, O. E. Public Management and Administration. An Introduction, 3-d edition, Houndmills etc., 2003. PP. 44-70.

Hood, C. A. Public Management for all Seasons? Public Administration 1/1991. - PP. 3-49.

Osborne, D. and Gaebler, T. (1992) 'Reinventing Government'. - PP. 2-18 ; 44-69.

Schröter, E. and Wollmann, H. (2001): New Public Management. PP. 63-97.

\section{НОВИЙ ПУБЛІЧНИЙ МЕНЕДЖМЕНТ: ДОСВІД США ДЛЯ УКРАЇНИ}

\author{
Віталій Хомицький, студент, магістр публічного управління та адміністрування, Київський націо- \\ нальний університет імені Тараса Шевченка (Украӥна), \\ ORCID: https://orcid.org/0000-0001-7909-7666, \\ Email:vitalii.khomytskyi@gmail.com \\ Отримано: 29.03.2019 \\ Ухвалено до друку: 13.05.2019
}

Опубліковано: 18.06.2019 
Хомичький В. (2020). Новий публічний менеджмент: досвід США для Украйни. Вісник Київського національного університету імені тараса Шевченка. Державне управління, (11), 46-52. https://doi.org/10.17721/2616-9193.2019/11-5/7

\section{Анотація}

Мета. Мета статті - проаналізувати ефективність проведення реформ, заснованих на концепиї нового публічного менеджменту, у США та виділити ключові елементи для застосування в Україні.

Методика. Результати дослідження були отримані такими методами: системним і компаративний методами - для визначення сутності та особливостей історичного становлення реформ нового публічного менеджменту в США, в основу яких покладено розуміння адміністративної діяльності крізь призму приватної економіки, орієнтачія державної служби на ефективність та результативність проиесу управління; методами аналізу і синтезу - для виявлення комплексних історичних факторів та інтересів, які зумовили становлення та функиіонування системи нового публічного менеджменту.

Результати. Відповідно до иілей дослідження автор:

1) встановив та проаналізував теоретичні джерела й методологічні засади дослідження концепиіі нового державного управління Т. Геблера та Д. Озборна;

2) з'ясував значення кониепиї нового державного менеджмента Т. Геблера та Д. Озборна для системи сучасних наукових досліджень публічного сектору;

3) розкрив зміст поняття нового державного менеджмента як адміністративного процесу;

4) проаналізував проблеми ефективності державного управління у контексті кониепиії нового публічного менеджменту під час проведення реформ у США;

5) визначив можливості застосування кониепиї нового публічного менеджменту при проведенні реформ сучасних адміністративних проиесів в Україні.

Наукова новизна. Запропоновано авторське бачення та інтерпретачія історичних чинників, шо привели до формування нового публічного менеджменту. Стаття містить аналіз історичних подій $i$ практичних наслідків проведених реформ у США.

Практична значимість. Враховуючи зміну влади в Україні та нестабільну економічну ситуачію через пандемію короновірусу, імплементачія елементів концепиії нового публічного менеджменту можуть сприяти підвищенню ефективності реформи державного кправління в Украйні. Матеріали статті можуть бути використані у практичі державного управління; при розробиі курсів з державного управління; для вдосконалення програм та планів навчання посадових осіб владних органів; у підготовці підручників, навчальних й методичних посібників.

Ключові слова: державне управління, новий публічний менеджмент, новий менеджменалізм, реформа. 